\title{
Kognitivní projevy interních onemocnění
}

\author{
doc. MUDr. Robert Rusina, Ph.D. ${ }^{1,2}$ - editor hlavního tématu \\ 'Neurologická klinika a Centrum klinických neurověd, 1. LF UK a VFN, Praha \\ ${ }^{2}$ Neurologické oddělení, Thomayerova nemocnice, Praha
}

\begin{abstract}
Motto:
Interní onemocnění mohou být provázena kognitivním postižením, které nemusí být na první pohled patrné, deficity v jednotlivých doménách (pamět', zrakově-prostorové nebo exekutivní funkce) se mnohdy překrývají, časté jsou poruchy chování a dezorientace; typický bývá i neklid či naopak apatie.

Cílem tohoto tématu je pryiblížit opomíjený aspekt interních onemocnění, uváděný v učebnicích mnohdy na konci kapitol, někdy i petitem, a pritom bývá dopad na pacienty významný a zdravotníky podceňovaný.

Rozpoznat a upresnit typ a rozsah kognitivních projevů u gastrointestinálních, jaterních, renálních nebo i některých systémových nemusí být snadné. Prripomíná to trochu citovaný bonmot slavného kanadského revmatologa z konce 19. století, v němž si stěžuje na obtíž-

mozkové tkáně (např. krvácení, ischemie, tumor, trauma).

- často kolísavé, někdy proměnlivé v čase, jindy může být stacionární nebo dokonce ustupující (např. po kompenzaci metabolického rozvratu) - tím se zásadně liší od typické chronické progrese u demencí.

- při správném odhalení príčiny a včasné adekvátní léčbě často reverzibilní, což jen potvrzuje předpoklad, že fungování jinak zdravých neuronů je "jen“ (více nebo méně) dočasně narušeno. Samozřejmě platí, že príliš intenzivní nebo dlouhodobé působení daných patofyziologických podnětů může způsobit poškození ireverzibilní a následný zánik neuronů. V těchto prípadech pak samožrejmě ani odstranění prričiny už nemusí vést k odeznění kognitivních projevư úplně bez následků.
\end{abstract}

„When a patient with arthritis walks in the front door, I feel like leaving out the back door." Sir William Osler (1849-1919) nost léčby revmatických onemocnění a i určitý nevděk od některých pacientů.

Vedle prímých poškození mozkové tkáně (např. zánětlivým procesem) je časté nespecifické postižení při současně probíhajícím porušení vnitřního prostředí organizmu.

\section{Kognitivní postižení}

\section{je v těchto prípadech:}

- dáno působením „vnějších“ vlivů na intaktní neurony (např. hyponatrémie, urémie, intoxikace). Nejedná se tedy o prímý důsledek specifických intraneuronálních procesů (např. depozita hyperfosforylovaného tau proteinu) nebo nezvratnou destrukci
Užitečným vyšetřením u encefalopatií je EEG, jako v prípadě typických trifazických pomalých vin u jaterní encefalopatie. Nálezy jsou však většinou nespecifické (zpomalení základní aktivity, pomalé delta a theta vlny, často difuzně). Diferenciálně diagnosticky může být užitečná neprítomnost epileptických grafoelementů.

$\checkmark$ souvislosti s encefalopatiemi se často vyskytují i amentně - delirantní stavy, označované dřive jako stavy zmatenosti. Zpravidla vždy se jedná o príznak difuzního postižení mozku ze zevních příčin, v rámci metabolické nebo elektrolytové dysbalance, při zhoršení celkového stavu, v průběhu infekčních onemocnění aj.
V popředí je časoprostorová dezorientace, špatné soustredění i pozornost, chování je ovlivněno neklidem s agresivitou, časté jsou úzkostné stavy nebo halucinace, komunikace s nemocným bývá obtižná. Velmi přiznačné jsou doprovodné somatické projevy od třesu přes opocení, subfebrilie, po tachykardii, hyperventilaci a zvýšení krevního tlaku. Patognomický je akutní (vzácněji subakutní) začátek a výrazné kolísání stavu, i v rozmezí několika málo hodin od těžkého postižení do prakticky normálního stavu. Nezbytné je v těchto prípadech nalézt a odstranit vyvolávající príčinu, poté zmíněné klinické projevy zpravidla rychle ustoupí.

Amentně-delirantní stav může být u starších lidí i projevem dekompenzace dosud klinicky „němé" demence v rámci interního nebo jiného onemocnění, proto i po odeznění těchto symptomů by měli být pacienti ambulantně sledováni.

Kognitivní postižení u gastrointestinálních a jaterních onemocnění může být důsledkem prímého postižení mozkové tkáně (neurologické manifestace Whippleovy nebo Wilsonovy nemoci), důsledkem deficitu nutričních faktorů (Wernickeova encefalopatie a Korsakovův syndrom $\checkmark$ rámci malnutrice nebo jako komplikace bariatrické chirurgie, hypovitaminóza $B_{12} u$ atrofické gastritidy), může komplikovat jaterní selhávání a cirhózu, ale může se objevit i v rámci hepatitidy $C$.

U systémových onemocnění kognitivní poruchy provázejí nejčastěji systémový lupus erythematodes (SLE) a v menší míře i revmatoidní artritidu (RA), nebo Sjögrenův syndrom.

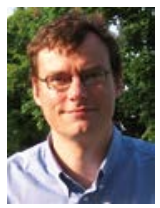

KORESPONDENČNII ADRESA AUTORA: doc. MUDr. Robert Rusina, Ph.D., robert.rusina@lf1.cuni.cz Neurologická klinika a Centrum klinických neurověd 1. LF UK a VFN, Praha Kateřinská 30, 12000 Praha 2 


\section{EDITORIAL}

KOGNITIVNÍ PROJEVY INTERNÍCH ONEMOCNĚNÍ

Kortikoidy indukované neuropsychiatrické poruchy byly popsány především u pacientů se SLE léčených kortikoidy. Je zajímavé, že podobné kortikoterapií indukované manifestace se ve větší míře nevyskytují u jiných autoimunitních a systémových onemocnění.

Endokrinní onemocnění mohou vyvolat různé neurologické obrazy, od incipientní myopatie až po akutní encefalopatii. Kognitivní dysfunkce je častá u poruch funkce štítné žlázy (hypotyreó- za, hypertyreóza, Hashimotova encefalopatie při autoimunitní tyreoiditidě), rostoucí pozornost je věnována vlivu dlouhodobého poklesu hladiny estrogenu po menopauze na kognitivní výkonnost a riziko rozvoje Alzheimerovy nemoci, i vztahu mezi diabetem a Alzheimerovou nemocí. Kognitivní projevy u chronického renálního selhání jsou často na podkladě encefalopatie. Je ale důležité rozlišovat projevy samotného onemocnění ledvin a komplikace navozené dialýzou.
Závěrem Ize shrnout, že ačkoliv mnohé neurologické projevy interních chorob jsou v širším medicínském povědomí poměrně dobře známy, kognitivní postižení, jako symptom gastrointestinálních, jaterních nebo endokrinních onemocnění je mnohdy nerozpoznáno, málo se po něm cíleně pátrá a přitom může výrazně zhoršit pacientův celkový stav, při vhodné léčbě může však být i reverzibilní. 